\title{
Torrefaction of Oil Palm Frond Petiole: Effect of Particle Sizes, Sections and Batches
}

\author{
Muhammad Ariff Hanaffi Mohd Fuada, Eljoji J. A. Loijon ${ }^{\mathrm{a}}$, Mohd Faizal Hasan ${ }^{\mathrm{a}, \mathrm{d}, *}$, Mohd Rosdzimin Abdul \\ Rahman ${ }^{\mathrm{b}}$, Bemgba B. Nyakuma ${ }^{\mathrm{c}}$, Shaharil Mad Saad

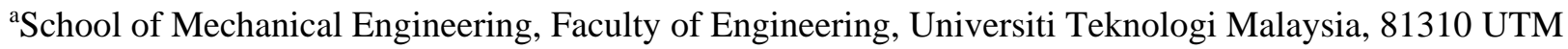 \\ Johor Bahru, Johor, Malaysia. \\ ${ }^{b}$ Department of Mechanical Engineering, Faculty of Engineering, Universiti Pertahanan Nasional Malaysia, \\ Kem Sungai Besi, 57000 Kuala Lumpur, Malaysia \\ ${ }^{\mathrm{c}}$ School of Chemical and Energy Engineering, Faculty of Engineering, Universiti Teknologi Malaysia, 81310 \\ UTM Johor Bahru, Johor, Malaysia. \\ ${ }^{\mathrm{d}}$ Automotive Development Centre (ADC), Institute for Vehicle System and Engineering, Universiti \\ Teknologi Malaysia, 81310 UTM Johor Bahru, Johor, Malaysia.
}

*Corresponding author: mfaizal@mail.fkm.utm.my

\author{
Article History \\ Received: December 30, 2020 Received in revised form: April 16, $2021 \quad$ Accepted: April 17, $2021 \quad$ Published Online: June 30, 2021
}

\begin{abstract}
This study aimed to investigate the effect of batches (1, 2 and 3), particle sizes ( $<250 \mu \mathrm{m}$, range of $300 \mu \mathrm{m}$ to $500 \mu \mathrm{m})$, and sections (bottom, middle and top) on combustion performance of the oil palm frond (OPF) petiole after torrefaction at $275{ }^{\circ} \mathrm{C}$. The higher heating value (HHV), mass yield, energy yield, HHV yield and proximate analyses of the untorrefied and torrefied OPF petiole for all cases were determined. The comparison between the untorrefied and torrefied OPF petiole as well as an international benchmark was also performed. In this study, the highest HHV of the torrefied OPF petiole $(22.85 \pm 0.07 \mathrm{MJ} / \mathrm{kg})$ was obtained at the bottom section with the particle size of $<250 \mu \mathrm{m}$. Furthermore, the fixed carbon content of the torrefied OPF petiole increased, whereas the volatile matter, moisture content, mass and energy yields decreased for all cases after torrefaction. HHV yield of OPF petiole was recorded up to $141 \%$ after torrefaction. The ash content was sufficiently satisfied the international benchmark for most cases, except for top section $(300-500 \mu \mathrm{m})$. The changes in combustion properties of the torrefied OPF petiole for all cases were found to be insignificant whereas significant improvement could be observed when compared to untorrefied OPF petiole. Overall, the study revealed that the appropriate particle size for torrefaction can promote it to be a vital source for energy production from oil palm biomass.
\end{abstract}

Keywords: Torrefaction, oil palm frond, petiole, particle size, batch

\subsection{INTRODUCTION}

The sustainable development goal (SDG) "Affordable and clean energy" seeks to sustainably change the energy production landscape entirely. Hence, minimizing the use of fossil-based energy is one of the approaches. Alternatively, clean energy from renewable sources (such as biomass, wind, solar, etc.) is a good potential alternative to replace fossilbased energy sources for energy consumption. The abundant sources of biomass such as agricultural and forestry have increased the potential for bioenergy utilization in Malaysia. The largest source of agricultural waste streams annually generated in Malaysia is from the oil palm industry [1].

According to the report of the Malaysian Palm Oil Board (MPOB) in 2016 [2], about 56.45 million tonnes of oil palm waste ranging from empty fruit bunch to oil palm frond was generated. Oil palm fronds (OPF) contributed about 
$7 \%$ of waste from the total oil palm waste, hence promoting its utilization, as a vital energy source. Several studies have reported that raw OPF can be potentially upgraded to become a promising energy source similar to empty fruit bunch (EFB), palm kernel shell (PKS), and mesocarp fibre (MSF). This is due to its significant amount of carbon content, which typically ranges from 40.30 to $48.43 \%$ [1,3-9]. In the energy production, the amount of energy (known as higher heating value, HHV) that can be produced during the combustion of a fuel is vital [10], along with other requirements such as conversion efficiency, pollutant emissions, etc [11]. For the case of raw OPF, its HHV is typically considered low in the range from 16.3 to $18.1 \mathrm{MJ} / \mathrm{kg}$ [4-9,12-14]. Hence, as an effort in enhancing its performance, the pre-treatment such as torrefaction is necessarily suitable.

Torrefaction is a pre-treatment process that solely focuses on the enhancement of solid-state fuel properties in an inert environment [15]. During torrefaction, the properties of the solid biomass fuel are significantly improved and sometimes higher than coal when heating at a modest temperature ranges from $200{ }^{\circ} \mathrm{C}$ to $300{ }^{\circ} \mathrm{C}$ [16]. Furthermore, there are two reactions that normally involved in torrefaction; mild $\left(200-250{ }^{\circ} \mathrm{C}\right)$ and severe $\left(250-300{ }^{\circ} \mathrm{C}\right)$. In most reported studies [16-21], severe torrefaction conditions significantly improved the fuel properties of torrefied biomass rather than the mild condition. This phenomenon is mainly due to the relatively high intensity of the biomass degradation process. This condition decomposes the lignocellulose components of biomass and further increases the carbon and fixed carbon contents of biomass [16,17]. Torrefied biomass has also shown potential performance for numerous applications such as combustion and gasification, which resulted in high combustion rates, high-quality syngas production and low toxic gas emissions [22,23] if compared coal-based energy source.

The torrefaction of oil palm wastes such as EFB, PKS, and MSF is prominently examined based on various parameters; namely particle sizes, temperatures, and residence times [15,24,25]. In the case of OPF, the effect of torrefaction temperature $[4,6,27,7-9,12-14,16,26]$ residence time [8,12] and flow rate of nitrogen gas [14] on the performance of OPF have been reported in several studies. The effect of torrefaction temperature on the torrefied OPF performance seem to be dominant compared to the other parameters. This can be found when the torrefaction temperature is increased, the HHV of torrefied OPF is enhanced (19.3 to $29.22 \mathrm{MJ} / \mathrm{kg}$ ) [5,6,8,9,12,13,26,27], carbon content (44.5 to $56.68 \%)[5,7,8]$ ) and fixed carbon content (12.68 to $57.1 \%)$ [7,8,13,26,27] of torrefied OPF also increases.

Since OPF consists of petiole, rachis, and leaflet components [28-32], the authors believe that none of the research studies have investigated the effect of a specific component of OPF, sections and particle sizes through torrefaction of OPF. Therefore, it can be said that the aforementioned effect on the torrefaction of OPF can become a novel study to be explored. Meanwhile, the other studies have shown that the component of OPF has promising chemical compositions (i.e lignocellulose components, sugar, etc.) in which suitably used for various applications; chemicals [29], bio-materials [32], and other biofuels [32], bio-ethanol [33,34], and bio-mulch [35]. In addition, the petiole and stem contain 66\% and $34 \%$ sugar content, respectively, which can be converted into energy [36].

Therefore, this study aims to fundamentally understand the effect of different sections and particle sizes of the petiole from three different batches of OPF on the performance of torrefied products. In this study, the petiole of three different batches of OPF was examined along with the particle sizes $<250 \mu \mathrm{m}$ and $300-500 \mu \mathrm{m}$ for each batch of the OPF petiole at $275^{\circ} \mathrm{C}$ during the torrefaction process. The torrefaction temperature of $275^{\circ} \mathrm{C}$ has been found to significantly improve the combustion performance and fuel properties (i.e HHV, mass yield, energy yield, proximate and ultimate analysis) of torrefied biomass from previous studies regardless of the raw materials [19,24,25]. The physical appearance, mass yield, higher heating value (HHV), energy yield, HHV yield and proximate analysis of untorrefied and torrefied petiole of OPF were evaluated for each batch and particle sizes and subsequently compared with the international benchmarks.

\subsection{MATERIAL AND METHODS}

\subsection{Material}

The OPF was collected from a palm oil mill located in Kota Tinggi, Johor. Three batches (labelled with batch one, two and three) of OPF with a total length of $1.78 \mathrm{~m}$ from the same oil palm plantation area were used in this study. The OPF for all batches was naturally dried of around three weeks and subsequently separated into two parts with a length of 1.08 $\mathrm{m}$ for the petiole and $0.7 \mathrm{~m}$ for the rachis as shown by Figure 1. In this study, the OPF petiole of each batch was used, while the other components of OPF (i.e the rachis and leaflets) were discarded. Next, the petiole of each batch was separated into five sections labelled as; section 1-bottom, 2 and 3-middle, 4 and 5-top) with a similar length of $216 \mathrm{~mm}$ (see Figure 1 (c) and (d)). The petiole of the OPF with the sections labelled 1-bottom, 3-middle and 5-top were subsequently selected for further tests. The selected petiole sections (1-bottom, 3-middle and 5-top) of each batch were then pulverized separately by using the crushing machine (Model: RETSCH BB50, Germany) and sieved through a sieve shaker machine (Model: RETSCH type AS200 digit, Germany) to obtain particle size of $<250 \mu \mathrm{m}$ and $300-500 \mu \mathrm{m}$. Table 1 shows the properties of the different sections and particle sizes of the raw OPF petioles examined in this study. 


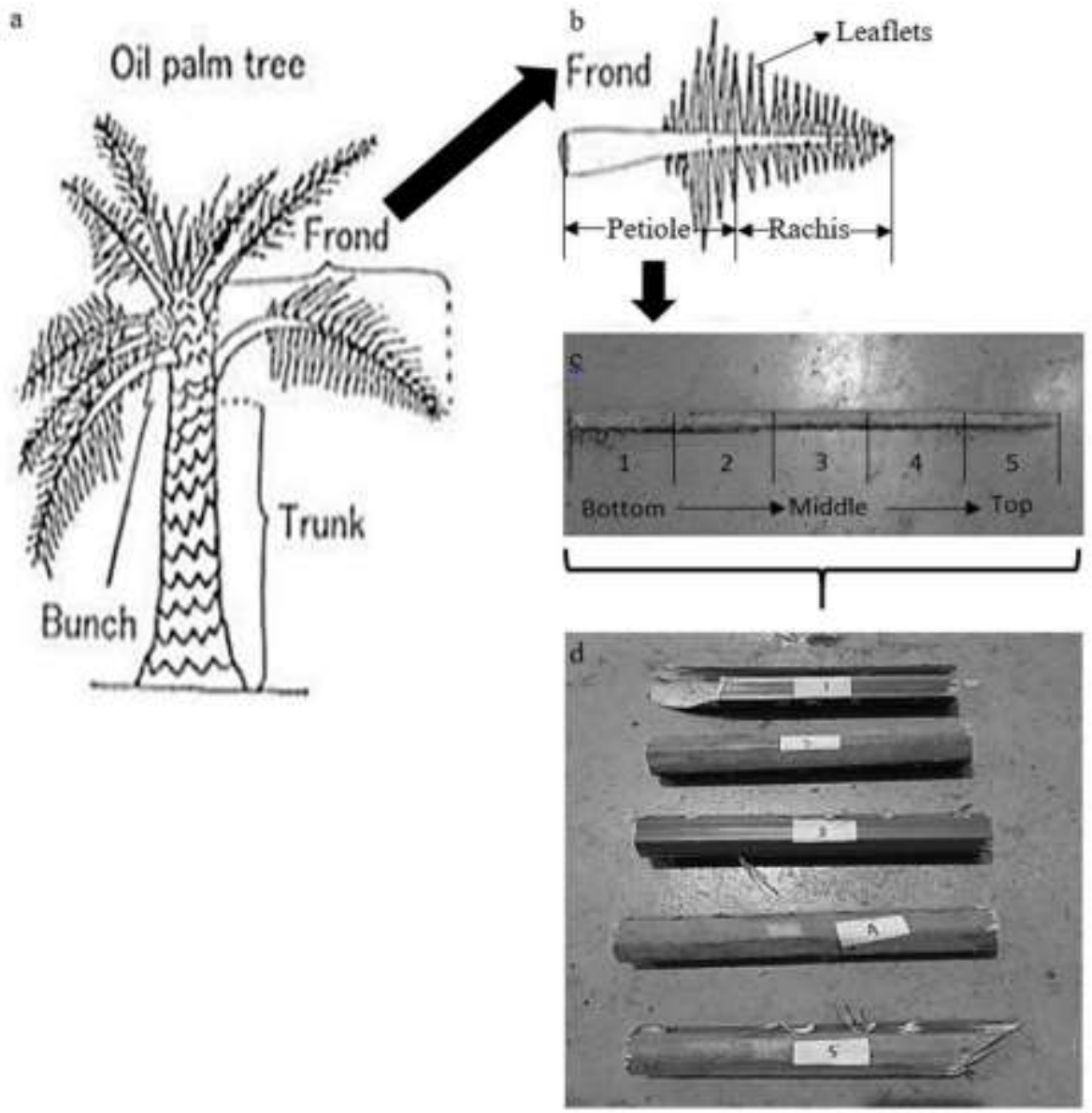

Figure 1 Oil palm tree (a) [37], oil palm frond (OPF) and parts (b) [37], various sections of OPF petiole (c) and separated OPF petiole (d) used in this study

Table 1 Properties of untorrefied oil palm frond petiole for each batch and particle sizes

\begin{tabular}{|c|c|c|c|c|c|c|}
\hline \multirow[t]{2}{*}{ Batch } & \multirow[t]{2}{*}{ Condition } & \multicolumn{4}{|c|}{ Proximate analysis (wt,\%) } & \multirow{2}{*}{$\begin{array}{c}\text { Higher heating } \\
\text { value, } \mathrm{HHV} \\
(\mathrm{MJ} / \mathrm{kg})\end{array}$} \\
\hline & & $\begin{array}{l}\text { Moisture } \\
\text { content }\end{array}$ & Volatile matter $^{d}$ & $\begin{array}{c}\text { Ash } \\
\text { Content }^{\mathrm{d}}\end{array}$ & Fixed carbon".d & \\
\hline 1 & OPF petiole-bottom $(<250 \mu \mathrm{m})$ & $9.25 \pm 0.30$ & $75.87 \pm 0.55$ & $3.38 \pm 0.04$ & $20.75 \pm 0.51$ & $17.21 \pm 0.47$ \\
\hline \multirow[t]{6}{*}{2} & OPF petiole-bottom $(<250 \mu \mathrm{m})$ & $9.87 \pm 0.23$ & $78.12 \pm 0.50$ & $4.32 \pm 0.1$ & $17.48 \pm 0.40$ & $16.26 \pm 0.45$ \\
\hline & OPF petiole-middle $(<250 \mu \mathrm{m})$ & $11.78 \pm 0.31$ & $76.39 \pm 0.32$ & $3.59 \pm 0.04$ & $20.02 \pm 0.29$ & $16.06 \pm 0.36$ \\
\hline & OPF petiole-top $(<250 \mu \mathrm{m})$ & $10.18 \pm 0.44$ & $75.38 \pm 0.19$ & $4.18 \pm 0.03$ & $20.44 \pm 0.16$ & $15.94 \pm 0.12$ \\
\hline & $\begin{array}{l}\text { OPF petiole-bottom } \\
500 \mu \mathrm{m})\end{array}$ & $10.68 \pm 0.73$ & $74.55 \pm 0.21$ & $3.24 \pm 0.05$ & $22.21 \pm 0.14$ & $15.80 \pm 0.06$ \\
\hline & $\begin{array}{l}\text { OPF petiole-middle } \\
500 \mu \mathrm{m})\end{array}$ & $10.18 \pm 0.44$ & $75.38 \pm 0.19$ & $4.23 \pm 0.13$ & $20.39 \pm 0.33$ & $15.52 \pm 0.08$ \\
\hline & OPF petiole-top $(300-500 \mu \mathrm{m})$ & $10.63 \pm 0.00$ & $74.34 \pm 0.00$ & $4.58 \pm 0.01$ & $21.08 \pm 0.01$ & $15.26 \pm 0.13$ \\
\hline 3 & OPF petiole-bottom $(<250 \mu \mathrm{m})$ & $11.73 \pm 0.66$ & $77.32 \pm 0.93$ & $3.31 \pm 0.08$ & $20.38 \pm 0.00$ & $17.00 \pm 0.34$ \\
\hline Benchmark & & $<10^{\mathrm{a}}$ & & $<5^{\mathrm{b}}$ & & $>20^{\mathrm{c}}$ \\
\hline
\end{tabular}

For all conditions, the untorrefied OPF petioles exhibited considerably high moisture and volatile matter contents, showing that the samples are hygroscopic. Due to its hygroscopic nature, untorrefied OPF petiole has low HHV and fixed 
carbon content which could be useful in direct combustion [41] after torrefaction pretreatment is applied. Lastly, the ash content of raw OPF petiole can be also considerably low.

\subsection{Torrefaction of OPF Petiole}

In this study, the experimental method and schematic diagram for the torrefaction process are based on our previous studies $[19,25,42]$. The torrefaction of OPF petiole was performed in a vertical reactor (internal diameter, ID $=100 \mathrm{~mm}$; height, $\mathrm{H}=150 \mathrm{~mm}$ ) equipped with a clamp heater on the outer surface of the reactor wall. The torrefaction temperature was controlled by using a K-type thermocouple sensor connected to a PID controller. The tip of the K-type thermocouple sensor was set at $5 \mathrm{~mm}$ above the pulverized OPF petiole. In this study, the OPF petiole was torrefied at a constant temperature and nitrogen flow rate of $275^{\circ} \mathrm{C}$ and $1 \mathrm{~L} / \mathrm{min}$, respectively.

Initially, $4 \mathrm{~g}$ of pulverized OPF petiole was weighed and put in the rectangular-shaped stainless steel crucible before placing inside the reactor. Subsequently, the lid of the reactor was sealed tightly to initiate purging for an hour at a constant nitrogen flow rate of $1 \mathrm{~L} / \mathrm{min}$. The pulverized OPF petiole was later heated to the desired torrefaction temperature of $275^{\circ} \mathrm{C}$ in an inert environment for 30 minutes. When the residence time of the torrefaction process was attained, the temperature was reset to an ambient condition to allow the torrefied pulverized OPF petiole to cool inside in the reactor with a continuous flow of nitrogen. Finally, the torrefied pulverized OPF petiole was removed and sealed in a sealed bag before stored in a desiccator.

\subsection{Characterization of Untorrefied and Torrefied OPF Petiole}

In this study, the proximate analysis of untorrefied and torrefied OPF petiole was determined in accordance with the standard methods; EN ISO 18134-2:2015 for moisture content [38], EN ISO 18123:2015 for volatile matter [43], and EN ISO 18122:2015 for ash content [39]. The higher heating values (HHV) of the raw and torrefied OPF petiole were determined by bomb calorimetry (Model: IKA C2000, USA). The mass and energy yields [44], as well as higher heating value (HHV) yield [45] were determined from equations 1, 2 and 3, respectively:

$$
\begin{gathered}
\text { Mass yield }(\%)=\frac{\text { Mass of torrefied pulverized OPF petiole }(g)}{\text { Mass of untorrefied pulverized OPF petiole }(g)} \times 100 \% \\
\text { Energy yield }(\%)=\text { Mass yield } \times \frac{H H V \text { of torrefied pulverized OPF petiole }\left(\frac{\mathrm{MJ}}{\mathrm{kg}}\right)}{H H V \text { of untorrefied pulverized OPF petiole }\left(\frac{\mathrm{MJ}}{\mathrm{kg}}\right)} \\
\text { Higher heating value yield }(\%)=\frac{\text { HHV of torrefied pulverized OPF petiole }\left(\frac{\mathrm{MJ}}{\mathrm{kg}}\right)}{\text { HHV of untorrefied pulverized OPF petiole }\left(\frac{\mathrm{MJ}}{\mathrm{kg}}\right)} \times 100 \%
\end{gathered}
$$

\subsection{RESULTS AND DISCUSSION}

\subsection{Higher Heating Value of Torrefied OPF Petiole for Various Conditions}

Figure 2 ( $a$ and $b$ ) show the higher heating value (HHV) of the OPF petiole torrefied at various particle sizes with sections and batches, respectively. In the case of OPF petiole for batch 2 torrefied at various particle sizes and sections, generally, the HHV of OPF petiole increased after torrefaction. In terms of the effect particle size of the OPF petiole from batch 2 , the torrefied OPF petiole with the particle size of $<250 \mu \mathrm{m}$ at bottom section recorded a relatively high HHV of $22.85 \pm 0.07 \mathrm{MJ} / \mathrm{kg}$ compared to the torrefied OPF petiole with the particle size of 300 to $500 \mu \mathrm{m}(20.05 \pm 0.08 \mathrm{MJ} / \mathrm{kg})$. At the middle and top section, the HHV of the torrefied OPF with the particle size of $<250 \mu \mathrm{m}$ recorded HHV of $20.40 \pm 0.00 \mathrm{MJ} / \mathrm{kg}$ and $19.85 \pm 0.03 \mathrm{MJ} / \mathrm{kg}$, respectively. In contrast, the HHV for 300 to $500 \mu \mathrm{m}$ samples at the middle was $19.83 \pm 0.05 \mathrm{MJ} / \mathrm{kg}$, whereas the top section was $18.65 \pm 0.10 \mathrm{MJ} / \mathrm{kg}$. The phenomenon is mainly due to the enhanced heat transfer typically observed in smaller particle sizes $(<250 \mu \mathrm{m})[46]$, which thermally degrades the lignocellulosic components.

Meanwhile, for the case of the different sections from the same particle size of $<250 \mu \mathrm{m}$, the HHV of torrefied OPF petiole from the bottom section recorded a highest HHV of $22.85 \pm 0.07 \mathrm{MJ} / \mathrm{kg}$ compared to the other sections $(20.40 \pm 0.00 \mathrm{MJ} / \mathrm{kg}$ for the middle section and $19.85 \pm 0.03 \mathrm{MJ} / \mathrm{kg}$ for the top section). This phenomenon was also found in the case of the HHV of the bottom to top section of torrefied OPF petiole with a particle size of 300 to $500 \mu \mathrm{m}$. Based on the findings, it is asserted that the bottom section of the petiole may contain more carbon that potentially converted into higher energy after torrefaction. However, the proximate results of fixed carbon do not really imply this situation, that is supposed due to the inhomogeneity of the torrefied surface of OPF. On the other hand, it may also contain less complex lignocellulose components than other sections due to the dissimilar HHV observed regardless of the particle sizes examined. Generally, the values of HHV of torrefied OPF petiole examined at bottom section (particle size of $<250 \mu \mathrm{m}$ ), middle section (particle size of $<250 \mu \mathrm{m}$ ) and bottom section (particle size of $300-500 \mu \mathrm{m}$ ) were higher than the international benchmark. In contrast to that, the HHV of the torrefied OPF petiole at the top section (particle size of 
$<250 \mu \mathrm{m}$ and $300-500 \mu \mathrm{m}$ ) and at the middle section (particle size of $300-500 \mu \mathrm{m}$ ) did not fulfil the benchmark requirements.

The study on the bottom section of OPF petiole with the particle size of less than $250 \mu \mathrm{m}$ for various batches was further investigated as shown in Figure 2 (b). The HHV of the torrefied OPF petiole for all batches observably increased compared to the untorrefied OPF petiole. The HHV of OPF petiole for batch 1 increased from $17.21 \pm 0.47 \mathrm{MJ} / \mathrm{kg}$ to $23.12 \pm 0.03 \mathrm{MJ} / \mathrm{kg}, 16.26 \pm 0.45 \mathrm{MJ} / \mathrm{kg}$ to $22.85 \pm 0.07 \mathrm{MJ} / \mathrm{kg}$ for batch 2 and $17.00 \pm 0.34 \mathrm{MJ} / \mathrm{kg}$ to $21.85 \pm 0.58 \mathrm{MJ} / \mathrm{kg}$ for batch 3 . Hence, the difference in HHV among various batches after torrefaction was insignificant, showing that the various batches of OPF petiole are comprised of similar properties and could be competitively utilized for energy production. However, the HHV of the torrefied of OPF petiole for each batch fulfilled the requirements as stated by international benchmarks. Overall, the moderate amount recorded by HHV of torrefied OPF petiole if compared to the other torrefied oil palm biomass (i.e torrefied EFB, MSF, and PKS. This phenomenon is mainly due to the presence of relatively high hemicellulose and cellulose $[31,47,48]$ in an overall OPF petiole compared to the other types of oil palm biomass.
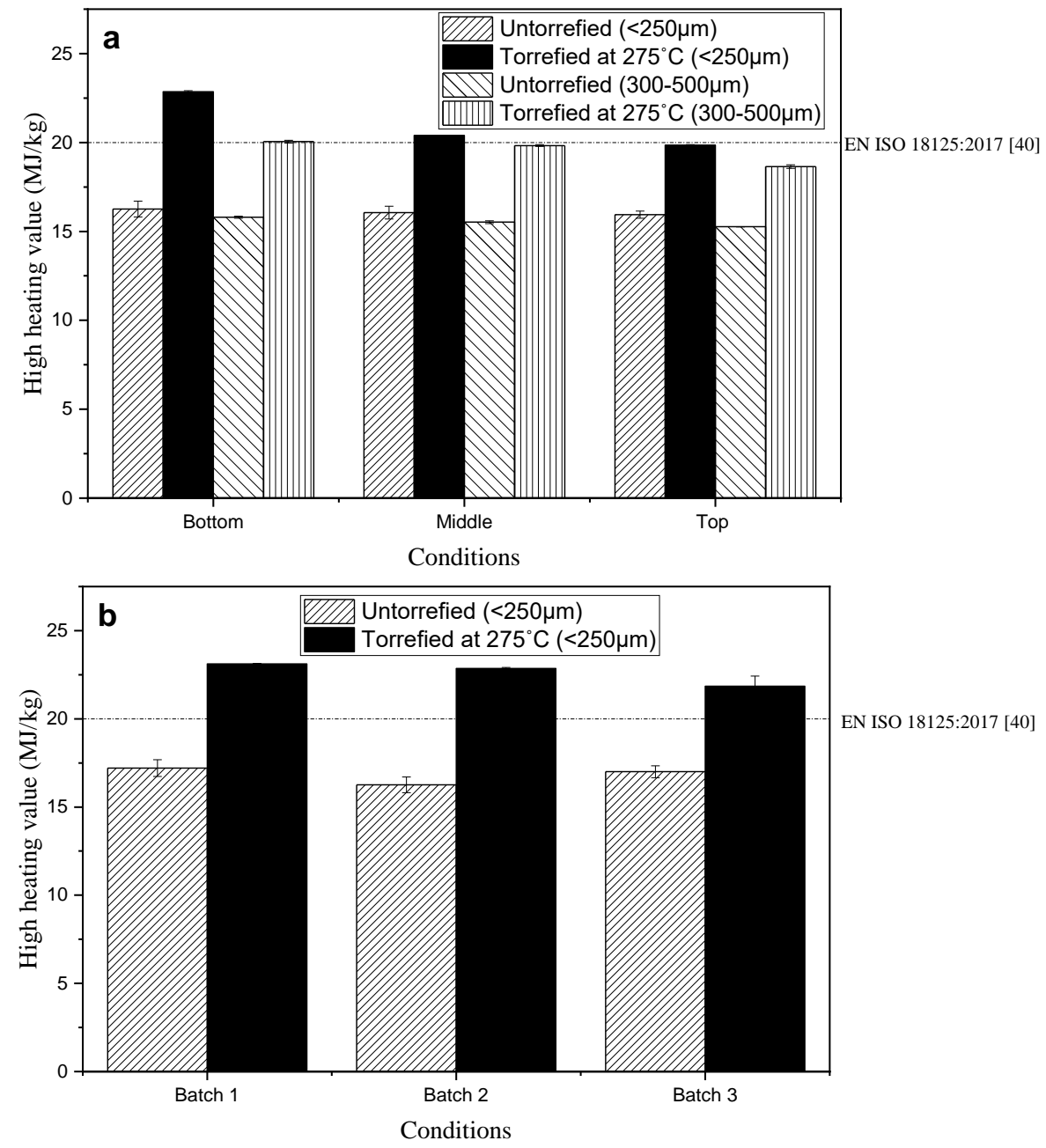

Figure 2 Higher heating value of untorrefied and torrefied OPF petiole: a) at batch 2 for various particle sizes and sections, and $b$ ) at a particle size of $<250 \mu \mathrm{m}$ for various batches

\subsection{Proximate Analysis of Torrefied OPF Petiole at Various Conditions}

Table 2 shows the proximate analysis of torrefied OPF petiole for various particle sizes and sections. In the case of the different particle sizes of the torrefied OPF petiole, it was found that the fixed carbon of torrefied OPF petiole for bottom section increased slightly from $35.18 \pm 0.39$ to $40.81 \pm 0.27 \mathrm{db} \%$ when particle size is increased from $<250 \mu \mathrm{m}$ to particle size with a range of 300 to $500 \mu \mathrm{m}$. In the case of torrefied OPF petiole for middle and top sections, however, the fixed carbon decreased from $40.73 \pm 1.43$ to $35.65 \pm 0.27 \mathrm{db} \%$ ( $<250 \mu \mathrm{m}$ to particle size with a range of 300 to $500 \mu \mathrm{m})$ and $37.07 \pm 1.17$ to $37.81 \pm 0.13 \mathrm{db} \%$ ( $<250 \mu \mathrm{m}$ to particle size with a range of 300 to $500 \mu \mathrm{m})$, respectively. Generally, the fixed carbon of the torrefied OPF petiole for all particle sizes and sections is considerably higher than the untorrefied OPF petiole, showing that torrefaction at severe conditions (temperature $=275^{\circ} \mathrm{C}$ ) greatly improved the properties of the $\mathrm{OPF}$ petiole. However, based on Table 2, for the case of bottom part, the proximate results of fixed carbon do not really reflect 
the trend of HHV increment when particle is decreased. This is supposed due to the inhomogeneity of certain part of OPF petiole, in which same experience has been faced by Uemura et al. [15] when investigating the change in ash content of empty fruit bunch (EFB) after being torrefied.

The ash content and volatile matter of OPF petiole for all particle sizes and sections have recorded insignificant changes after torrefaction. The ash content was observed in the range $4.11 \pm 0.05$ to $5.57 \pm 0.12 \mathrm{db} \%$, while the volatile matter was $54.67 \pm 1.48$ to $59.97 \pm 0.28 \mathrm{db} \%$. However, compared to the untorrefied OPF petiole, the ash content of the torrefied OPF petiole increased up to $72 \%$, although the volatile matter decreased by $30 \%$ for all particle sizes and sections. In the case of ash content, some studies have reported that the low vaporization of the alkali salts in ash, in which torrefaction condition is performed increases the ash content of torrefied OPF petiole for all conditions [15,49]. Based on the present findings, the ash content of torrefied OPF petiole at different sections and particle sizes fulfilled the requirements as stated by the international benchmark except for the top section of torrefied OPF petiole with particle size of the range $300-500 \mu \mathrm{m}$. Meanwhile, the moisture content of the torrefied OPF petiole for all particle sizes and sections was observed within the range $5.97 \pm 0.15$ to $7.48 \pm 0.19 \%$, although it is considerably decreased when compared to the untorrefied $\mathrm{OPF}$ petiole for all particle sizes and sections. This phenomenon is mainly due to the severe torrefaction condition (temperature of $275^{\circ} \mathrm{C}$ ) phase caused deoxygenation [7], which fulfills the requirement as stated by EN ISO 18134-2:2015 (<10\%) [38].

Table 2 Properties of oil palm frond petiole from batch 2 for various sections and particle sizes after torrefaction

\begin{tabular}{|c|c|c|c|c|c|c|}
\hline Batch & Condition & Proximate an & sis $(w t, \%)$ & & & Higher heating \\
\hline \multirow{9}{*}{2} & & $\begin{array}{c}\text { Moisture } \\
\text { content }\end{array}$ & Volatile matter $^{\text {d }}$ & Ash content $^{\mathrm{d}}$ & Fixed carbon ${ }^{*}, \mathrm{~d}$ & \\
\hline & OPF petiole-bottom $(<250 \mu \mathrm{m})$ & $5.97 \pm 0.15$ & $59.97 \pm 0.28$ & $4.86 \pm 0.11$ & $35.17 \pm 0.39$ & $22.85 \pm 0.07$ \\
\hline & OPF petiole-middle $(<250 \mu \mathrm{m})$ & $5.97 \pm 0.15$ & $54.67 \pm 1.48$ & $4.59 \pm 0.04$ & $40.73 \pm 1.43$ & $20.40 \pm 0.00$ \\
\hline & OPF petiole-top $(<250 \mu \mathrm{m})$ & $6.85 \pm 0.15$ & $58.13 \pm 0.87$ & $4.80 \pm 0.30$ & $37.07 \pm 1.17$ & $19.85 \pm 0.03$ \\
\hline & OPF petiole-bottom & $6.66 \pm 0.15$ & $55.08 \pm 0.23$ & $4.11 \pm 0.05$ & $40.81 \pm 0.27$ & $20.05 \pm 0.08$ \\
\hline & $500 \mu \mathrm{m})$ & & & & & \\
\hline & OPF petiole-middle & $6.22 \pm 0.10$ & $59.38 \pm 0.06$ & $4.97 \pm 0.21$ & $35.65 \pm 0.27$ & $19.83 \pm 0.05$ \\
\hline & $500 \mu \mathrm{m})$ & & & & & \\
\hline & OPF petiole-top $(300-500 \mu \mathrm{m})$ & $7.48 \pm 0.19$ & $56.62 \pm 0.01$ & $5.57 \pm 0.12$ & $37.81 \pm 0.13$ & $18.65 \pm 0.10$ \\
\hline Benchmark & & $<10 \%{ }^{\mathrm{a}}$ & & $<5 \%{ }^{\mathrm{b}}$ & & $>20 \%^{\mathrm{c}}$ \\
\hline
\end{tabular}

The proximate analysis of the torrefied OPF petiole of the bottom section for each batch with a particle size of $<250 \mu \mathrm{m}$ is shown in Table 3. Generally, the fixed carbon of the torrefied OPF petiole of the bottom section considerably increased after torrefaction compared to the untorrefied OPF petiole of the bottom section. From Table 3, the fixed carbon of the torrefied OPF petiole of the bottom section was $39.78 \pm 0.26 \mathrm{db} \%$ for batch $1,35.18 \pm 0.39 \mathrm{db} \%$ for batch 2 , and $38.02 \pm 1.92 \mathrm{db} \%$ for batch 3 . The volatile matter of the torrefied OPF petiole of the bottom section for all batches was recorded from $55.81 \pm 0.04$ to $59.97 \pm 0.28 \mathrm{db} \%$, showing that the severe torrefaction condition (temperature of $275^{\circ} \mathrm{C}$ ) intensely degraded the hemicellulose and cellulose [5] components of OPF petiole. In the case of the ash content of torrefied OPF petiole of the bottom section, it was found that the ash content for batch 1 and 2 were $4.40 \pm 0.22 \mathrm{db} \%$ and $4.86 \pm 0.11 \mathrm{db} \%$, respectively. However, for batch 3 a lower ash content $(3.58 \pm 0.31 \mathrm{db} \%)$ was observed for the torrefied OPF petiole of the bottom section. Referring to this phenomenon, although alkali and alkaline earth materials (AAEMs) are not examined in this study, it is worth to said that, the uneven AAEMs within OPF petiole could possibly occur due to grinding effect [50], that in turn, cause an uncontrollable of fine AAEMs during preparation stage and subsequently increase the ash content when the biomass undergoes thermal treatment [51].

In this study, the moisture content of the bottom section of torrefied OPF petiole for all batches decreased to within the range of $6.41 \pm 0.20$ to $5.15 \pm 0.20 \%$ if compared to the untorrefied OPF petiole of the bottom section $(9.25 \pm 0.30$ 
to $11.73 \pm 0.66 \%$ ). Therefore, this proves that the vaporization of moisture occurred during torrefaction. Overall, it can be surmised that the moisture content and an ash content of torrefied OPF petiole for different batches have fulfilled the requirement stated based on EN ISO 18134-2:2015 (<10\%) [38] and EN ISO 18122:2015 [39], respectively.

Table 3 The properties of oil palm frond petiole (bottom part with particle size $<250 \mu \mathrm{m}$ ) for all batches after torrefaction

\begin{tabular}{|c|c|c|c|c|c|c|}
\hline \multirow[t]{2}{*}{ Batch } & \multirow[t]{2}{*}{ Condition } & \multicolumn{4}{|c|}{ Proximate analysis (wt,\%) } & \multirow{2}{*}{$\begin{array}{l}\text { High heating } \\
\text { value, HHV } \\
(\mathrm{MJ} / \mathrm{kg})\end{array}$} \\
\hline & & $\begin{array}{l}\text { Moisture } \\
\text { content }\end{array}$ & Volatile matter ${ }^{d}$ & $\begin{array}{l}\text { Ash } \\
\text { content }^{\text {d }}\end{array}$ & Fixed carbon ${ }^{*}, \mathbf{d}$ & \\
\hline 2 & OPF petiole-bottom $(<250 \mu \mathrm{m})$ & $5.97 \pm 0.15$ & $59.97 \pm 0.28$ & $4.86 \pm 0.11$ & $35.18 \pm 0.39$ & $22.85 \pm 0.07$ \\
\hline 3 & OPF petiole-bottom $(<250 \mu \mathrm{m})$ & $6.41 \pm 0.20$ & $58.40 \pm 1.61$ & $3.58 \pm 0.31$ & $38.02 \pm 1.92$ & $21.85 \pm 0.58$ \\
\hline Benchmark & & $<10 \%{ }^{\mathrm{a}}$ & & $<5 \%{ }^{\mathrm{b}}$ & & $>20 \%{ }^{c}$ \\
\hline
\end{tabular}

\subsection{Mass Yield, Energy Yield and Higher Heating Value Yield of Torrefied OPF Petiole}

Figure 3(a) shows the mass and energy yields for torrefied OPF petiole of batch 2 at various particle sizes and sections. The mass yield of the torrefied OPF petiole with particle sizes $<250 \mu \mathrm{m}$ for all cases was slightly lower than the mass yield of torrefied OPF petiole with a particle size of 300 to $500 \mu \mathrm{m}$. For example, at the bottom section, the mass yield of torrefied OPF petiole with the particle size of $<250 \mu \mathrm{m}$ was $50.63 \%$, while $55.85 \%$ was recorded for torrefied OPF petiole at 300 to $500 \mu \mathrm{m}$. Similar trend was also found for the torrefied OPF petiole with a particle size of $<250 \mu \mathrm{m}$ and 300 to $500 \mu \mathrm{m}$ at the middle section (51.25\% and 54.72\%, respectively). In addition, mass yield for the torrefied OPF petiole with particle size $<250 \mu \mathrm{m}$ and 300 to $500 \mu \mathrm{m}$ at the top section was $51.65 \%$ and $55.83 \%$, respectively. Lower mass yield for particle size of $<250 \mu \mathrm{m}$ regardless of section is mainly due to enhanced heat transfer within particles with smaller sizes [46], which significantly degrades the lignocellulose components of torrefied OPF petiole [9].

The energy yield of the bottom section of the torrefied OPF petiole was $71.15 \%$ (for the particle size $<250 \mu \mathrm{m}$ ) and $70.88 \%$ (for 300 to $500 \mu \mathrm{m}$ ). However, the middle section has an energy yield of $65.10 \%$ (for the particle size $<250 \mu \mathrm{m}$ ) and $69.92 \%$ (for particle size of 300 to $500 \mu \mathrm{m}$ ), whereas the top section exhibited $64.32 \%$ (for the particle size $<250 \mu \mathrm{m}$ ) and $68.24 \%$ (for particle size of 300 to $500 \mu \mathrm{m}$ ). Based on the findings, generally, the energy yield is slightly increased for middle and top sections when particle size is increased (from $<250 \mu \mathrm{m}$ to the range 300 to $500 \mu \mathrm{m}$ ), but, conversely occur for the case of bottom section. This phenomenon is supposedly due to the insignificant improvement of HHV of torrefied OPF petiole for middle and top sections while for bottom section, the energy yield is dominated by a significant improvement of $\mathrm{HHV}$ of torrefied OPF petiole. When compared with similar particle size (i.e $<250 \mu \mathrm{m}$ ) for all sections, the improvement of HHV of torrefied OPF petiole was more pronounced than that for particle size of 300 to $500 \mu \mathrm{m}$. The results are well agreed by Ahiduzzaman and Islam [52] that the improvement of HHV of torrefied biomass is more influential than that of mass yield for the case of energy yield. Also, these phenomena can be noticeable in this study when the HHV yield of torrefied OPF petiole (particle size of $<250 \mu \mathrm{m}$ for bottom section) recorded highest of about $141 \%$ than other conditions (HHV yield of ranging 122 to $128 \%$ ).

The mass and energy yields of torrefied OPF petiole for various batches with the particle size of $<250 \mu \mathrm{m}$ are shown in Figure 3(b). Based on the figure, it can be seen that the mass yields of torrefied OPF petiole recorded insignificant difference between batches, showing that each batch experienced similar devolatilization at severe torrefaction condition $\left(275^{\circ} \mathrm{C}\right)$. This phenomenon can be seen when OPF petiole is torrefied, the mass yield obtained was within the range of 51.23 to $53.61 \%$. However, in this study, the energy yield of the torrefied OPF petiole was found to slightly differ between batches. For example, the energy yield of torrefied OPF petiole was recorded at 68.82\% (batch 1), $71.15 \%$ (batch 2) and $68.91 \%$ (batch 3). From the results, it can be surmised that the difference in energy yield of the torrefied OPF petiole is more affected by the improvement of HHV [52] (with HHV yield of ranging 129 to $141 \%$ ) rather than the effect of mass yield of torrefied biomass. 

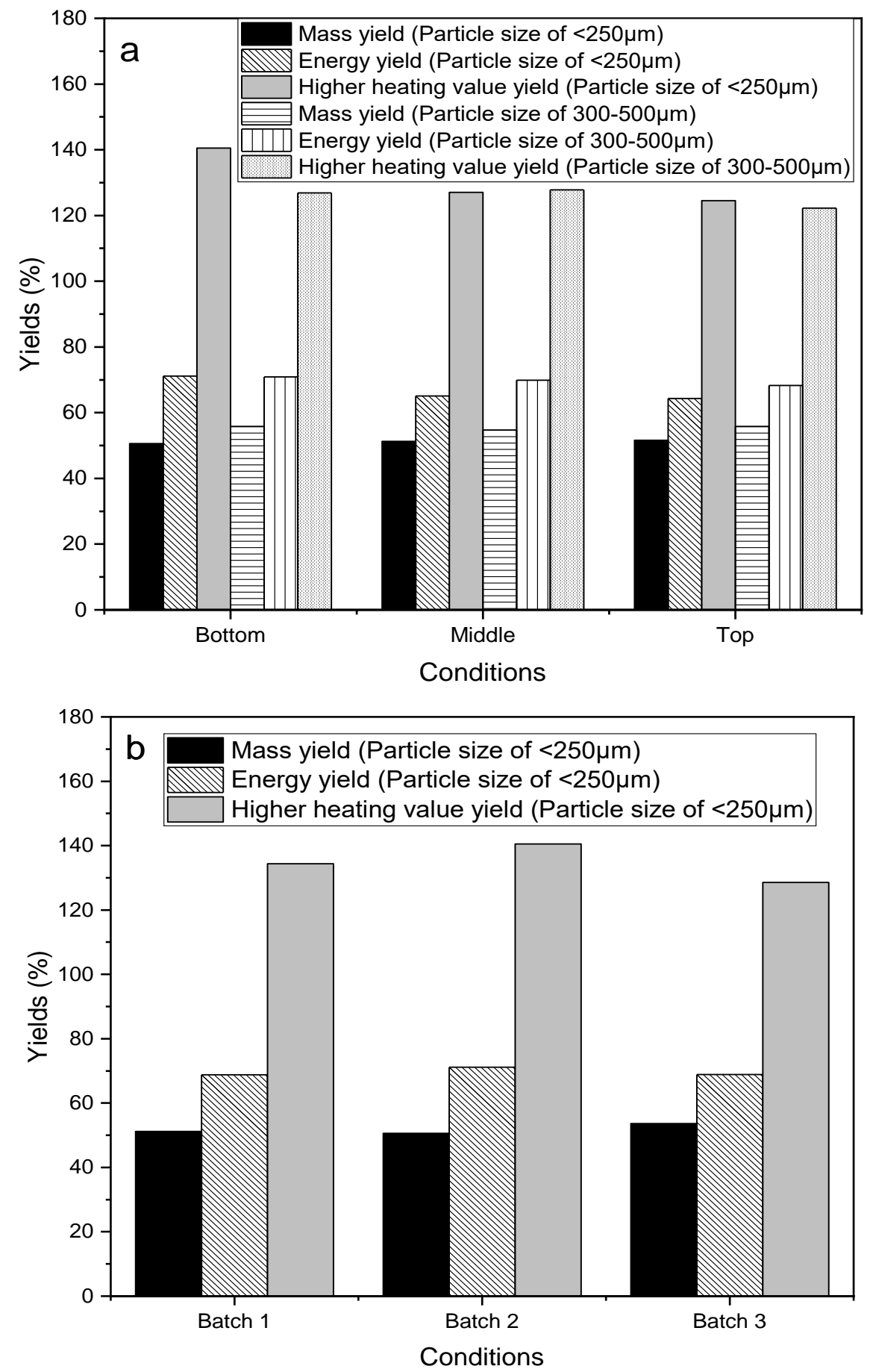

Figure 3. Mass and energy yields of torrefied OPF petiole: a) at batch 2 for various particle sizes and sections, and $b)$ at a particle size of $<250 \mu \mathrm{m}$ for various batches.

\subsection{CONCLUSION}

The torrefaction process was performed at $275^{\circ} \mathrm{C}$ to fundamentally examine the effect of torrefaction on the combustion properties of oil palm frond (OPF) petiole for various particle sizes, sections, and batches. In this study, the effect of particle size and section are found to be more pronounced than the effect of batches for the case of HHV. For both particle sizes, higher HHV was recorded for bottom section, while decrease when the section is approaching top section. It is observed that the change of HHV for each batch was insignificant, which within the range of $21.85 \pm 0.58$ to $23.12 \pm 0.03 \mathrm{MJ} / \mathrm{kg}$. Generally, the fuel properties of the OPF petiole improved after torrefaction. It can be deduced that the pulverized petiole of bottom section with particle size of less than $250 \mu \mathrm{m}$ gives the highest energy yield. From this 
study, it is worth to said that the OPF petiole has potential to be used as solid fuel source due to improved performance after torrefaction.

\section{Acknowledgements}

The authors acknowledge the Ministry of Higher Education (MoHE) Malaysia, and Universiti Teknologi Malaysia (UTM) for the full cooperation received for this research activity. The authors wish to thank the Research Management Centre (RMC) for the Tier 2 grant (VOT No.: 16J28) from MoHE and UTM.

\section{References}

[1] Loh, S. K.. 2017. The Potential of the Malaysian Oil Palm Biomass as a Renewable Energy Source. Energy Convers. Manag., 141: 285-298.

[2] Malaysian Palm Oil Board (MPOB), 2016, Malaysian Oil Palm Statistics 2016, MPOB, ministry of plantation industries and commodities.

[3] Sukiran, M. A., Abnisa, F., Wan Daud, W. M. A., Abu Bakar, N., and Loh, S. K. 2017. A Review of Torrefaction of Oil Palm Solid Wastes for Biofuel Production. Energy Convers. Manag. 149:101-120.

[4] N.N. Omar, N. Abdullah, I. S. M. and F. S. 2019. Characterisation of Oil Palm Frond for Bio-Oil Production. ASM Science Journal 11(1): 9-22.

[5] Wahid, F. R. A. A., Harun, N. H. H. M., Rashid, S. R. M., Samad, N., and Saleh, S. 2017. Physicochemical Property Changes and Volatile Analysis for Torrefaction of Oil Palm Frond. Chemical Engineering Transactions. 56:199-204.

[6] Thaim, T., Rasid, R. A., and Ismail, W. M. S. W. 2019. Torrefaction of Oil Palm Fronds (OPF) as a Potential Feedstock for Energy Production Processes. Journal of Environmental Engineering and Landscape Management. 27(2): 64-71.

[7] Matali, S., Rahman, N. A., Idris, S. S., Yaacob, N., and Alias, A. B. 2016. Lignocellulosic Biomass Solid Fuel Properties Enhancement via Torrefaction. Procedia Engineering, Elsevier, 671-678.

[8] Yaacob, N., Rahman, N. A., Matali, S., and Idris, S. S. 2017. Torrefaction of Oil Palm Frond: Effects of Torrefaction Temperature and Holding Time. AIP Conference Proceedings, AIP Publishing, 100003.

[9] Sukiran, M. A., Abnisa, F., Daud, W., Bakar, N. A., Aziz, A. A., and Loh, S. K. 2019. Upgrading of Oil Palm Biomass by Torrefaction Process: A Preliminary Study. AIP Conference Proceedings, AIP Publishing, 20059.

[10] Arce, M. E., Saavedra, Á., Míguez, J. L., Granada, E., and Cacabelos, A. 2013. Biomass Fuel and Combustion Conditions Selection in a Fixed Bed Combustor. Energies. 6(11): 5973-5989.

[11] Chen, D., Yang, Q., Jiang, X., Lv, G., Ma, Z., Yan, J., Cen, K., Yu, X., Liao, H., and Zhao, H. 2016. Comparison of Combustion and Emission Characteristics of an Indonesian Lignite Washery Tailing Slurry with a Bituminous Coal in a Bench-Scale Bubbling/Circulating Fluidized Bed Combustor. Energy \& Fuels. 30(12): 10835-10846.

[12] Sulaiman, S. A., and Anas, M. I. 2012. Torrefaction of Oil Palm Fronds for Enhancement of Fuel Quality. Trends in Applied Sciences Research 7:248-255.

[13] Wahid, F. R. A. A., Saleh, S., and Samad, N. A. F. A. 2017. Estimation of Higher Heating Value of Torrefied Palm Oil Wastes from Proximate Analysis. Energy Procedia. 138: 307-312.

[14] Susanty, W., and Helwani, Z. 2018. Torrefaction of Oil Palm Frond: The Effect of Process Condition to Calorific Value and Proximate Analysis. IOP Conference Series: Materials Science and Engineering, IOP Publishing. 12016.

[15] Uemura, Y., Omar, W. N., Tsutsui, T., and Yusup, S. B. 2011. Torrefaction of Oil Palm Wastes. Fuel. 90(8): 2585-2591.

[16] Sulaiman, M. H., Uemura, Y., and Azizan, M. T. 2016. Torrefaction of Empty Fruit Bunches in Inert Condition at Various Temperature and Time. Procedia Engineering. 148:573-579.

[17] Chen, W.-H., and Kuo, P.-C. 2011. Torrefaction and Co-Torrefaction Characterization of Hemicellulose, Cellulose and Lignin as Well as Torrefaction of Some Basic Constituents in Biomass. Energy. 36(2):803-811.

[18] Faizal, H. M., Jusoh, M. A. M., Rahman, M. R. A., Syahrullail, S., and Latiff, Z. A. 2016. Torrefaction of Palm Biomass Briquettes at Different Temperature. Jurnal Teknologi 78:61-67.

[19] Fuad, M. A. H. M., Faizal, H. M., Rahman, M. R. A., and Latiff, Z. A. 2018. Torrefaction of Densified Empty Fruit Bunches with Addition of Plastics Waste. Biofuels. 1-11.

[20] Gucho, E. M., Shahzad, K., Bramer, E. A., Akhtar, N. A., and Brem, G. 2015. Experimental Study on Dry Torrefaction of Beech Wood and Miscanthus. Energies. 8(5):3903-3923.

[21] Ribeiro, J. M. C., Godina, R., Matias, J. C. de O., and Nunes, L. J. R. 2018. Future Perspectives of Biomass Torrefaction: Review of the Current State-of-the-Art and Research Development. Sustainability. 10(7):2323. 
[22] Chen, W.-H., Peng, J., and Bi, X. T. 2015. A State-of-the-Art Review of Biomass Torrefaction, Densification and Applications. Renew. Sustain. Energy Rev. 44:847-866.

[23] Zannikos, F., Kalligeros, S., Anastopoulos, G., and Lois, E. 2013. Converting Biomass and Waste Plastic to Solid Fuel Briquettes. Journal of Renewable Energy. 2013.

[24] Poudel, J., Ohm, T.-I., Gu, J. H., Shin, M. C., and Oh, S. C. 2017. Comparative Study of Torrefaction of Empty Fruit Bunches and Palm Kernel Shell. Journal of Material Cycles and Waste Management. 19(2):917-927.

[25] Faizal, H. M., Shamsuddin, H. S., Heiree, M. H. M., Hanaffi, M. F. M. A., Rahman, M. R. A., Rahman, M. M., and Latiff, Z. A. 2018. Torrefaction of Densified Mesocarp Fibre and Palm Kernel Shell. Renewable Energy. 122:419-428.

[26] Lau, H. S., Ng, H. K., Gan, S., and Jourabchi, S. A. 2018. Torrefaction of Oil Palm Fronds for Co-Firing in Coal Power Plants. Energy Procedia. $144: 75-81$.

[27] Rashid, S. R. M., Saleh, S., and Samad, N. A. F. A. 2017. Proximate Analysis and Calorific Value Prediction Using Linear Correlation Model for Torrefied Palm Oil Wastes. MATEC Web of Conferences, EDP Sciences. p. 4002.

[28] Aliyu, A. S., Aziz, A. A., Yahya, A., and Lattiff, Z. A. 2015. Potential Of Oil Palm Frond Liquid Extract And Fiber As Feedstock For BioButanol Production. Jurnal Teknologi. 74(10):. 63-67

[29] Ikubar, M. R. M., Manan, M. A., Salleh, M. M., and Yahya, A. 2018. Solid-State Fermentation of Oil Palm Frond Petiole for Lignin Peroxidase and Xylanase-Rich Cocktail Production. 3 Biotech. 8(5):259.

[30] Bulan, R., Tineke, M., and Wawan, H. Physical and Mechanical Properties of Palm Frond for the Development of Palm Oil Waste Chopper and Pressing Machine Design. International Journal of Scientific \& Engineering Research (IJSER). 6(2):117-120.

[31] Aina, F. N., Shuhaida, H., and Jamaliah, J. 2016. Physiochemical Changes and Mass Balance of Raw and Alkaline Pretreated Oil Palm Frond: Pressed versus Non-Pressed Sample. International Journal of Applied Engineering Research. 11(19):9886-9893.

[32] Roslan, A. M., Zahari, M. A. K. M., Hassan, M. A., and Shirai, Y. 2014. Investigation of Oil Palm Frond Properties for Use as Biomaterials and Biofuels. Tropical Agriculture and Development 58(1):26-29.

[33] Ooi, Z. X., Teoh, Y. P., Kunasundari, B., and Shuit, S. H. 2017. Oil Palm Frond as a Sustainable and Promising Biomass Source in Malaysia: A Review. Environ. Environmental Progress \& Sustainable Energy 36(6):1864-1874

[34] Hong, L. S., Ibrahim, D., and Omar, I. C. 2012. Oil Palm Frond for the Production of Bioethanol. International Journal of Biochemistry and Biotechnology 1(1):7-11.

[35] Mandang, T., Sinambela, R., and Pandianuraga, N. R. 2018. Physical and Mechanical Characteristics of Oil Palm Leaf and Fruits Bunch Stalks for Bio-Mulching. IOP Conference Series: Earth and Environmental Science, IOP Publishing. 12015.

[36] Malaysia Innovation Agency. 2011. National Biomass Strategy 2020. New Wealth Creat. Malaysia’s Palm Oil Ind. Malaysia.

[37] Ishida, M., and Abu Hassan, O. 19,97. Utilization of Oil Palm Frond as Cattle Feed. Japan Agricultural Research Quarterly. 31:41-48.

[38] EN ISO 18134-2:2015. 2015. Solid Biofuels-Determination of Moisture Content-Oven Dry Method-Part 2. 2.

[39] EN ISO 18122:2015. 2015. Solid Biofuels. Determination of Ash Content.

[40] EN ISO 18125: 2017. 2017. Solid Biofuels-Determination of Calorific Value.

[41] Huangfu, Y., Li, H., Chen, X., Xue, C., Chen, C., and Liu, G. 2014. Effects of Moisture Content in Fuel on Thermal Performance and Emission of Biomass Semi-Gasified Cookstove. Energy Sustain. Dev. 21:60-65.

[42] Faizal, H. M., Salleh, A. H. M., Shamsuddin, H. S., Ariff, M., Fuad, H. M., Latiff, Z. A., and Rahman, M. R. A. 2017. Torrefaction of Pulverized Empty Fruit Bunch and Polyethylene Plastics Waste Mixture. Journal of Advanced Research in Fluid Mechanics and Thermal Sciences. 29(1):1-

[43] EN ISO 18123:2015. 2015. Solid Biofuels - Determination of the Content of Volatile Matter.

[44] Lee, S. M., and Lee, J.-W. 2014. Optimization of Biomass Torrefaction Conditions by the Gain and Loss Method and Regression Model Analysis. Bioresource Technology. 172:438-443.

[45] Uemura, Y., Omar, W. N., Aziah, N., Othman, B., and Yusup, S. B. 2011. Effect of Atmosphere on Torrefaction of Oil Palm Wastes. World Renewable Energy Congress-Sweden; 8-13 May; 2011; Linköping; Sweden. 516-523.

[46] Peng, J. H., Bi, H. T., Sokhansanj, S., and Lim, J. C. 2012. A Study of Particle Size Effect on Biomass Torrefaction and Densification. Energy \& Fuels. 26(6):3826-3839. 
[47] Wang, X., Hu, J., Liang, Y., and Zeng, J. 2011. TCF Bleaching Character of Soda-Anthraquinone Pulp from Oil Palm Frond. BioResources. 7(1):275-282.

[48] Zakaria, M. R., Fujimoto, S., Hirata, S., and Hassan, M. A. 2014. Ball Milling Pretreatment of Oil Palm Biomass for Enhancing Enzymatic Hydrolysis. Appl. Biochem. Biotechnol. 173(7):1778-1789.

[49] Noda, R., Matsuhisa, Y., Ito, T., and Horio, M. 2003. Alkali Metal Evolution Characteristics of Wood Biomass during Pyrolysis and Gasification. Proceedings for the Annual Meeting of the Japan Institute of Energy, Japan, 196-197.

[50] Liu, X., and Bi, X. T. 2011. Removal of Inorganic Constituents from Pine Barks and Switchgrass. Fuel Processing Technology. 92(7):12731279.

[51] Abdullah, N., and Sulaiman, F. 2013. The Properties of the Washed Empty Fruit Bunches of Oil Palm. Journal of Physical Science 24(2):117137 .

[52] Ahiduzzaman, M., and Islam, A. K. M. S. 2015. Energy Yield of Torrefied Rice Husk at Atmospheric Condition. Procedia Engineering. 105:719-724. 